\title{
NDC pledges of South Asia: are the stakeholders onboard?
}

\section{A. K. Enamul Haque ${ }^{1} \cdot$ Heman D. Lohano $^{2}$ - Pranab Mukhopadhyay ${ }^{3}$ (D) Mani Nepal ${ }^{4}$ - Fathimath Shafeeqa ${ }^{5}$. Shamen P. Vidanage ${ }^{6}$}

Received: 21 October 2018 / Accepted: 15 March 2019 / Published online: 30 March 2019

(C) The Author(s) 2019

There is no doubt that the adverse impacts of climate change will affect a large proportion of the world's population, especially in South Asia which is home to over 25\% of the world's population. The vulnerability of the region is even greater because $33 \%$ of the world's poor live in this region (Alam and Rabbani 2007; World Bank 2017). However, for a country to fulfil the commitments made by the national government in the 2015 Paris Agreement (UNFCCC 2015), there is a need for coordinated action among all the stakeholders (government agencies, academia, the business organisations, and civil society organisations (CSOs). For coordination to occur, awareness and cooperation among stakeholders regarding the proposed Nationally Determined Contributions NDCs is essential (Averchenkova and Bass 2016). It is not self-evident that the NDC pledges of the six South Asian countries (Bangladesh, India, Maldives, Nepal, Pakistan, and Sri Lanka) were decided based on a bottom-up approach or even well communicated by the government to all the stakeholders. It is also not clear if the pledges made by the governments match feasible sets of climate change mitigation actions by stakeholders in South Asia.

Electronic supplementary material The online version of this article (https://doi.org/10.1007/s10584-01902417-6) contains supplementary material, which is available to authorized users.

\section{Pranab Mukhopadhyay}

pm@unigoa.ac.in
A. K. Enamul Haque
akehaque@ewubd.edu
Heman D. Lohano
hlohano@iba.edu.pk
Mani Nepal
mani.nepal@icimod.org
Fathimath Shafeeqa
fathimathshafeeqa@yahoo.com
Shamen P. Vidanage
shamen.vidanage@iucn.org

Extended author information available on the last page of the article 
It is therefore necessary to investigate whether the commitments made by the national governments (i.e. the chosen Greenhouse Gas (GHG) reduction strategies stated in the NDCs) are seen as essential and feasible strategies by other stakeholders (Taylor et al. 2014; Lee et al. 2015; Zhang et al. 2018). We do so by using primary data collected via a specially designed online survey instrument. Using the survey responses, we then develop a GHG Reduction Perception Index (GHGRPI) for the six countries. We find that while stakeholders in the six countries agree with the government pledges for GHG reduction, they differ on the modalities for reduction. The business organisations and CSOs, for example would prefer the governments to adopt incentive-based policies that would create an enabling environment for transport, industry, and agricultural sectors to adopt changes that would reduce their GHG footprints.

Even though the six countries are located in a contiguous region, they differ greatly both in terms of geographic characteristics as well as demographic, political, social, and economic characteristics. While the Maldives lies just $1 \mathrm{~m}$ above the mean sea level (Evans 2013) and faces the risk of submergence with predicted sea level rise due to climate change, Sri Lanka which is also an island country has both coastal and hilly regions. In contrast, Nepal is landlocked while also being home to the highest mountains in the world, which faces the challenge of faster melting of ice caps due to increased temperature. Bangladesh, India, and Pakistan, on the other hand, are home to diverse geography that includes large mountain ranges, hills, plains, and coastal zones.

Supplementary Table (SA1) summarises the basic characteristics of these countries in terms of the share of population and GHG emissions. It also provides a summary of the primary focus areas of the submitted NDC pledges (UNFCCC 2018). With the exception of Nepal, the other five countries have pledged to reduce the GHG emissions. Bangladesh, Maldives, and Sri Lanka have pledged to reduce their 2030 projected GHG emissions by 5 to $10 \%$ voluntarily and another 15 to $24 \%$ conditional on receiving resources from the global community. Pakistan has pledged to reduce its 2030 projected GHG emissions by $20 \%$ conditional on receiving international grants. India has pledged to reduce its emission intensity by up to $35 \%$ of its GDP by 2030. In the case of Nepal, the NDC document does not mention the intended reduction of the GHG emissions. This is probably because the country is already on a low emission growth path with $100 \%$ of its electricity generation sourced from hydropower in addition to recording a forest cover which exceeds $44 \%$ of the land area.

Despite the vast heterogeneity in characteristics and different levels of GHG emissions among the six countries, there are a number of similarities in the mitigation activities proposed by them in their NDCs. All six countries have pledged to promote renewable energy (solar, hydropower, and wind) as well as to convert waste to energy. They also have plans to increase the efficiency of the transportation sector by moving from fossil-fuel-based public transportation (buses) to electric trains and to increase their carbon sinks by enhancing the forest cover. Supplementary Table (SA1) gives the summary of intended GHG mitigation instruments proposed by the South Asian countries. However, fulfilling their pledges requires coordination among the various stakeholders as the governments alone cannot achieve these targets.

Since the objective of the study was to understand stakeholder perception, we constructed a perception index for the stakeholders using their responses to an online survey. We divided the stakeholders into two broad groups: (a) policymakers, i.e. individuals working in government agencies and academic institutions linked to policymaking, and (b) policy influencers, i.e. business organisations and CSOs. In the first group, we included those respondents who play essential roles in policy-making, research, and implementation vis-à-vis the government 
pledges of each country. In the second group, we included stakeholders who play essential roles in mitigation activities, in sectors dealing with such activities, or in lobbying for a cleaner environment in their countries. The two sets of respondents were chosen on the basis that one group is involved in policy-making while the other influences policy. In the first group are those who are either law-makers or administrators among whose tasks are listed the preparation of texts of laws, rules and regulations, and the representation of the government in international fora. Apart from law-makers, we included in this group academics who work with the government on the same or similar issues although, by themselves, they do not represent a clear pressure group. The second group consists of representatives of industry and CSOs. They are consulted by policymakers but do not actually formulate policy. The above classification has been adopted and modified to suit our purposes from the available literature on stakeholder analysis that uses a matrix of effective power and interest to classify different groups (Freeman 1984).

We gave equal weight to these two groups while constructing the perception index in the absence of any a priori weighing scheme (see Eq. 1). An index value of 100 means that all respondents agree with the statement while a zero value means that none agrees with the statement.

$$
\text { Index }_{i j}=\left(0.5 \times \frac{\text { Number of agreed responses from group } a_{i j}}{\text { Total respondents from group } a_{i j}}+0.5 \times \frac{\text { Number of agreed responses from group } b_{i j}}{\text { Total respondents from group } b_{i j}}\right) \times 100
$$

where $i=$ countries ( 1 to 6 ) and $j=$ strategies and actions ( 1 to 12 ) (see Table 1 ).

For the purposes of our survey, we prepared a list of potential agencies from which we identified specific respondents for survey purposes. The respondents were then sent an electronic mail with a link requesting them to complete an online survey. Keeping in mind that issues of relevance would be different from one country to another considering their diversity, we developed country-specific survey instruments. We pre-tested the draft questionnaires and revised them based on feedback received from those participating in the pre-tests. In the actual survey, the respondents were first asked to choose the country that they live in and then to fill in the country-specific questionnaire.

This was followed up with numerous request letters to potential respondents from the various categories. In all, we were able to contact 64 potential respondents from Bangladesh,

Table 1 Perception index on GHG reduction strategies and actions (\%)

\begin{tabular}{|c|c|c|c|c|c|c|}
\hline Selected strategies for GHG reduction & Bangladesh & India & Maldives & Nepal & Pakistan & Sri Lanka \\
\hline Improving traffic management & 95.8 & 100.0 & 61.4 & 96.9 & 56.0 & 38.5 \\
\hline Mini/micro/mega hydro & & & & 96.9 & & 1.9 \\
\hline Modernization of power plants & 95.8 & 70.1 & & & 54.6 & \\
\hline Promotion of waste to energy in municipalities & 95.8 & 60.4 & 56.8 & 96.9 & 51.2 & 53.8 \\
\hline Standardising energy efficient gadgets & 95.8 & 67.5 & & & 55.0 & \\
\hline $\begin{array}{l}\text { Promotion of improved cooking stoves } \\
\text { in rural areas }\end{array}$ & 91.7 & 82.8 & & 93.8 & & 53.9 \\
\hline Energy audits in factories & 90.3 & 71.1 & & & 56.3 & \\
\hline Promotion of solar irrigation pumps & 90.3 & 67.5 & & & 56.2 & \\
\hline Promotion of rooftop solar panels & 90.3 & 70.1 & 85.5 & 78.1 & 65.0 & 38.5 \\
\hline Promotion of SHS in remote and off-grid areas & 86.1 & 70.1 & & 63.9 & & 69.2 \\
\hline Promotion of solar mini-grids & 86.1 & 74.7 & 75.9 & 81.3 & & 42.3 \\
\hline Promotion of wind energy & 75.0 & 70.1 & & & 50.0 & 3.8 \\
\hline
\end{tabular}

Source: Authors' calculations based on primary data 
58 from India, 61 from the Maldives, 80 from Nepal, 50 from Pakistan, and 63 from Sri Lanka. The list included respondents from the following categories: civil servants; civil society activists/CSOs; transport operators; energy producers/ distributors/ transmitters/ regulators/ commissions; industry owners/managing directors; environmentalists; climate specialists; academics/researchers; and business organisations. The letters were then followed up with phone calls, emails, and visits in person to the respective institutions to identify individuals from whom to obtain responses. We completed data collection between November 2016 and April 2017. The 140 responses we received consequent to these efforts are used in the analysis. Among the respondents, there were $62 \%$ policymakers and $38 \%$ policy influencers (see Fig. 1 for a distribution of respondents).

We examine the responses under three different sub-themes/headings: awareness of the pledges; perception of GHG reduction strategies as proposed by the national governments; and perception of respondents on what they felt to be the most effective mitigation strategies vis-àvis GHG emissions. With equal weight assigned to each group in the six countries, the findings of the survey reveal that over $85 \%$ of the respondents are aware of the NDC pledges of their governments while over $75 \%$, barring respondents from Nepal, believe that reducing GHG emission should be one of the targets of their government. In the case of Nepal, only $50 \%$ of the respondents stated that GHG reduction should be one of the targets of the Nepal government. One possible reason for this difference could be that Nepal is already compliant with GHG targets.

The respondents from four of the six South Asian countries (India, Maldives, Pakistan, and Sri Lanka) were not very optimistic about meeting the NDC targets (Fig. 2). In contrast, 70\% of respondents from Bangladesh and Nepal are of the opinion that their countries are on target to achieving the NDC goals. Perhaps it is Nepal's high rate of forest cover at $44 \%$ and generation of $100 \%$ of its electricity from hydropower which makes the Nepalese content with their country's current level of engagement with GHG emission reduction. As for Bangladesh, perhaps it is the commencement of projects such as the metro rail and rapid bus transit projects

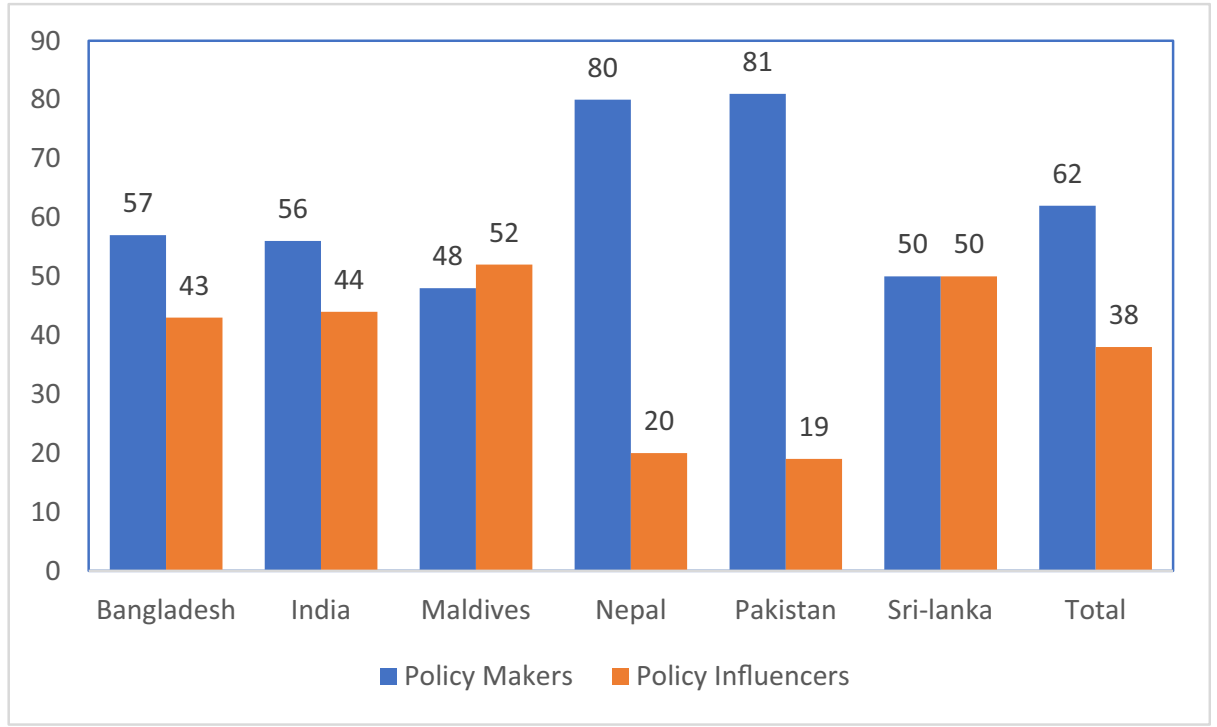

Fig. 1 Percentage distribution of respondents by country and group 


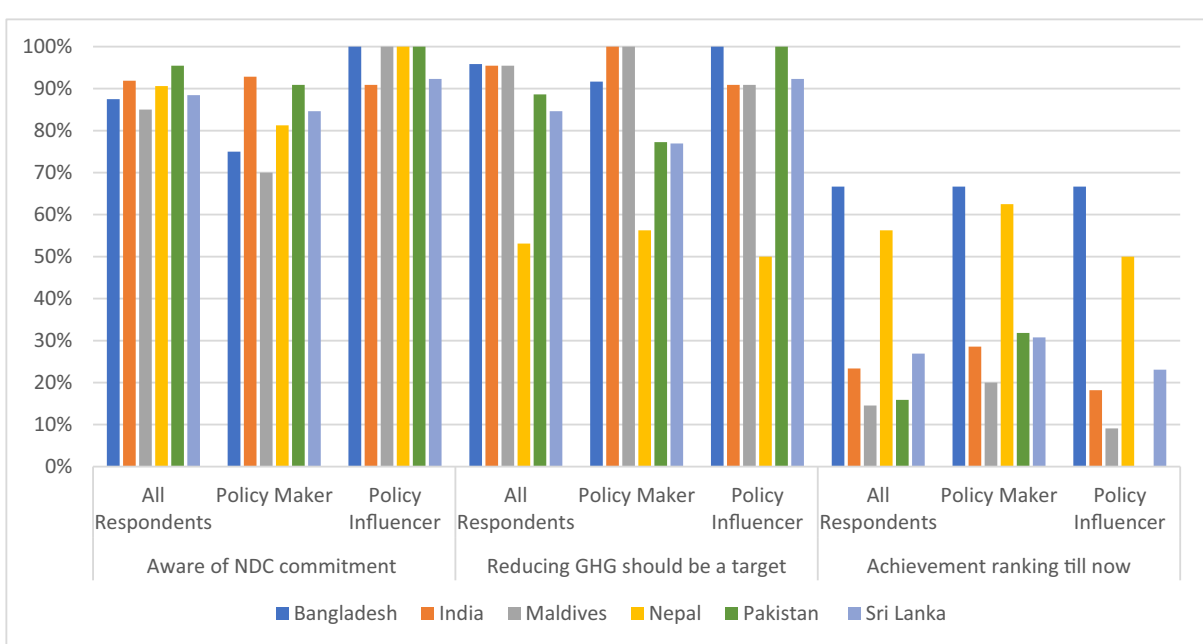

Fig. 2 NDC awareness and perceived achievement

by the state, which are in conformity with NDC pledges that explain the current levels of satisfaction of the Bangladeshis surveyed.

South Asian countries are currently experiencing extreme traffic congestion (Pucher et al. 2005), chronic power shortage (Qureshi et al. 2016), and the perennial problem of solid waste management (Srivastava et al. 2015). Table 1 presents the stakeholder perceptions of the GHG reduction strategies of their respective governments based on the perspectives expressed by those surveyed. The opinions of survey participants from all six countries make their concern with these issues very clear because they all identified traffic management, promotion of solar energy, and conversion of waste to energy as the main strategies for reducing GHG emissions.

We asked the respondents to rank the strategies listed in the NDC documents of their respective countries as well as some incentive-based mechanisms with regard to their effectiveness in reducing GHG emissions. For each country, we then picked the three best strategies as identified by the respondents ending up with 18 strategies for the six South Asian countries. We next discuss the responses of the two groups separately.

The results show that the policymaker group laid emphasis on investment-based policies with 11 of their 18 best choices leaning in that direction (see white cells in Table 2). In comparison, only five of their preferred choices were drawn from incentive-based policies (see yellow cells in Table 2). In addition, they shortlisted one strategy each of the regulation basedpolicies (see orange cells in Table 2) and awareness-based policies (see grey cells in Table 2).

In contrast, the policy influencer group laid emphasis on incentive-based policies with 11 of their 18 best choices leaning in that direction (see yellow cells in Table 3). Investment-based policies had a lower priority among them with five strategies (see orange cells in Table 3). Like the other group, they too selected regulation-based policies and awareness-based policies (see orange and grey cells in Table 3).

The contrasting responses of the two groups are noteworthy. Using the Spearman's Rank Correlation test, we found statistically significant differences between the rankings of the two groups for Bangladesh (at 10\%), Maldives (at 5\%), Nepal (at 5\%), and Pakistan (at 10\%), the level of significance for each country appearing in brackets. On the other hand, Sri Lanka and India did not exhibit such high differences in ranking between the two groups. 
Table 2 Policy makers' perceptions of GHG mitigation strategies in South Asia (three top choices)

\begin{tabular}{|c|c|c|c|c|c|}
\hline Bangladesh & India & Maldives & Nepal & Pakistan & Sri Lanka \\
\hline Energy audits & $\begin{array}{l}\text { Promotion of } \\
\text { Improved } \\
\text { cooking stoves in } \\
\text { rural areas }\end{array}$ & $\begin{array}{l}\text { Making } \\
\text { consumers } \\
\text { aware of energy } \\
\text { efficiency in } \\
\text { production and } \\
\text { consumption }\end{array}$ & $\begin{array}{l}\text { Investment in the } \\
\text { urban transport } \\
\text { system for cities }\end{array}$ & $\begin{array}{l}\text { Promotion of } \\
\text { rooftop solar power } \\
\text { production }\end{array}$ & $\begin{array}{c}\text { Promotion of } \\
\text { rooftop solar power } \\
\text { production }\end{array}$ \\
\hline $\begin{array}{l}\text { Efficient urban } \\
\text { transport system }\end{array}$ & $\begin{array}{l}\text { Promotion of } \\
\text { solar power }\end{array}$ & $\begin{array}{c}\text { Establishment of } \\
\text { environment } \\
\text { management } \\
\text { plan }\end{array}$ & $\begin{array}{c}\text { Promotion of } \\
\text { waste to energy } \\
\text { projects in } \\
\text { municipalities }\end{array}$ & $\begin{array}{l}\text { Investment in the } \\
\text { urban transport } \\
\text { system for cities }\end{array}$ & $\begin{array}{c}\text { Promotion of waste } \\
\text { to energy or } \\
\text { compost projects }\end{array}$ \\
\hline $\begin{array}{l}\text { Promoting energy } \\
\text { efficient power } \\
\text { production using } \\
\text { renewable } \\
\text { resources }\end{array}$ & $\begin{array}{l}\text { Promotion of } \\
\text { wind energy }\end{array}$ & $\begin{array}{l}\text { Promote waste } \\
\text { to energy in } \\
\text { municipalities }\end{array}$ & $\begin{array}{l}\text { Promotion of mini } \\
\text { and micro hydro } \\
\text { in off-grid areas }\end{array}$ & $\begin{array}{c}\text { Modernization of } \\
\text { power plants }\end{array}$ & $\begin{array}{l}\text { Promotion of } \\
\text { improved cooking } \\
\text { stoves }\end{array}$ \\
\hline
\end{tabular}

Yellow-coloured boxes represent incentive-based policies. Orange-coloured boxes represent regulation based policies. White boxes represent investment-based policies. Grey-coloured box represents awareness-based policies

Source: Authors' calculations based on primary data

This, in turn, means that investment-based mitigation plans and supports, which are popular among South Asian governments, international organisations, and bilateral donors, need careful re-examination. While developing countries have expressed the need for international assistance in order to fulfil their NDC pledges, our findings suggest that incentive-based mechanisms should also be considered alongside direct investment support. Hence, the

Table 3 Policy influencers' perception of GHG mitigation strategies in South Asia (three top choices)

\begin{tabular}{|c|c|c|c|c|c|}
\hline Bangladesh & India & Maldives & Nepal & Pakistan & Sri Lanka \\
\hline $\begin{array}{l}\text { Interest subsidy } \\
\text { for energy } \\
\text { efficient gadgets/ } \\
\text { investments }\end{array}$ & $\begin{array}{l}\text { Energy audits } \\
\text { for improving } \\
\text { energy } \\
\text { efficiency in } \\
\text { industries }\end{array}$ & $\begin{array}{c}\text { Making } \\
\text { consumers } \\
\text { aware of energy } \\
\text { efficiency in } \\
\text { production and } \\
\text { consumption }\end{array}$ & $\begin{array}{l}\text { Net metering to } \\
\text { promote solar } \\
\text { energy in grids }\end{array}$ & $\begin{array}{l}\text { Incentives for firms } \\
\text { to invest in energy } \\
\text { efficient gadgets }\end{array}$ & $\begin{array}{l}\text { Investment in } \\
\text { renewable energy } \\
\text { production }\end{array}$ \\
\hline $\begin{array}{l}\text { Incentives to } \\
\text { make firms } \\
\text { energy efficient }\end{array}$ & $\begin{array}{l}\text { Incentives to } \\
\text { make firms } \\
\text { energy efficient }\end{array}$ & $\begin{array}{l}\text { Appropriate } \\
\text { pricing to } \\
\text { improve energy } \\
\text { efficiency in the } \\
\text { transport sector }\end{array}$ & $\begin{array}{l}\text { Incentives to } \\
\text { make firms } \\
\text { energy efficient }\end{array}$ & $\begin{array}{l}\text { Appropriate pricing } \\
\text { for improving } \\
\text { energy efficiency in } \\
\text { the transport sector }\end{array}$ & $\begin{array}{l}\text { Incentives for } \\
\text { renewable energy } \\
\text { production using } \\
\text { mini and micro } \\
\text { hydropower projects }\end{array}$ \\
\hline $\begin{array}{l}\text { Waste to fertilizer } \\
\text { in urban areas }\end{array}$ & $\begin{array}{l}\text { Urban transport } \\
\text { system for cities }\end{array}$ & $\begin{array}{l}\text { Urban transport } \\
\text { system for } \\
\text { energy efficient } \\
\text { cities }\end{array}$ & $\begin{array}{l}\text { Interest subsidy } \\
\text { for energy } \\
\text { efficient gadgets/ } \\
\text { investments }\end{array}$ & $\begin{array}{l}\text { Subsidized loans for } \\
\text { energy efficient } \\
\text { gadgets }\end{array}$ & $\begin{array}{l}\text { Conversion of fuel } \\
\text { from petroleum } \\
\text { products to LNG }\end{array}$ \\
\hline
\end{tabular}

Cell colour schema same as in Table 2

Source: Authors' calculations based on primary data 
governments may need to consider designing appropriate strategies to create enabling environments for the adoption of low-carbon economic growth paths.

The most important finding emerging from the stakeholder responses is the need for governments to consider incentive-based policies to promote energy-efficient production and consumption to reduce GHG emissions in these countries. This would, in turn, bring all stakeholders on board as partners, who would play a significant role in the climate change mitigation endeavours of their respective national governments. The perception analysis suggests that non-government stakeholders want national governments to structure public policies regarding tax, subsidy, and other regulations in order to create incentives for firms to become energy efficient. Our study however did not examine whether the incentive based mechanisms would work better than direct investment projects in the current context and is a question that future research would need to address.

Acknowledgments The authors acknowledge the research assistance from Sabrina Eusa and Ashraf Uddin Mian of the Asian Centre for Development, Dhaka. Data collection for this paper was funded by Transparency International, Bangladesh. Comments from the editor and two anonymous reviewers of this journal are gratefully acknowledged. They helped improve the discussion significantly.

Open Access This article is distributed under the terms of the Creative Commons Attribution 4.0 International License (http:/creativecommons.org/licenses/by/4.0/), which permits unrestricted use, distribution, and reproduction in any medium, provided you give appropriate credit to the original author(s) and the source, provide a link to the Creative Commons license, and indicate if changes were made.

\section{References}

Alam M, Rabbani MDG (2007) Vulnerabilities and responses to climate change for Dhaka. Environ Urban 19: 81-97. https://doi.org/10.1177/0956247807076911

Averchenkova A, Bass S (2016) Beyond the targets: assessing the political credibility of pledges for the Paris Agreement

Evans A (2013) Climbing the highest point in the Maldives. In: Digital Nomad. http://digitalnomad. nationalgeographic.com/2013/11/05/climbing-the-highest-point-in-the-maldives/. Accessed 16 May 2018

Freeman RE (1984) Strategic management: a stakeholder approach. Pitman, Boston

Lee TM, Markowitz EM, Howe PD et al (2015) Predictors of public climate change awareness and risk perception around the world. Nat Clim Chang 5:1014-1020. https://doi.org/10.1038/nclimate2728

Pucher J, Korattyswaropam N, Mittal N, Ittyerah N (2005) Urban transport crisis in India. Transp Policy 12:185198. https://doi.org/10.1016/j.tranpol.2005.02.008

Qureshi MI, Rasli AM, Zaman K (2016) Energy crisis, greenhouse gas emissions and sectoral growth reforms: repairing the fabricated mosaic. J Clean Prod 112:3657-3666. https://doi.org/10.1016/j.jclepro.2015.08.017

Srivastava V, Ismail SA, Singh P, Singh RP (2015) Urban solid waste management in the developing world with emphasis on India: challenges and opportunities. Rev Environ Sci Biotechnol 14:317-337. https:/doi. org/10.1007/s11157-014-9352-4

Taylor AL, Dessai S, Bruine de Bruin W (2014) Public perception of climate risk and adaptation in the UK: a review of the literature. Clim Risk Manag 4-5:1-16. https://doi.org/10.1016/j.crm.2014.09.001

UNFCCC (2015) Paris Agreement

UNFCCC (2018) INDC - Submissions. http://www4.unfccc.int/Submissions/INDC/Submission\%20 Pages/submissions.aspx. Accessed 16 May 2018

World Bank (2017) SDG Atlas 2017. In: Data | World Bank. http://datatopics.worldbank.org/sdgatlas/SDG-01no-poverty.html. Accessed 16 May 2018

Zhang B, van der Linden S, Mildenberger M et al (2018) Experimental effects of climate messages vary geographically. Nat Clim Chang 8:370-374. https://doi.org/10.1038/s41558-018-0122-0

Publisher's note Springer Nature remains neutral with regard to jurisdictional claims in published maps and institutional affiliations. 


\section{Affiliations}

A. K. Enamul Haque ${ }^{1} \cdot$ Heman D. Lohano $^{2} \cdot$ Pranab Mukhopadhyay $^{3} \cdot$ Mani Nepal $^{4}$. Fathimath Shafeeqa ${ }^{5}$. Shamen P. Vidanage ${ }^{6}$

1 Department of Economics, East West University, Dhaka, Bangladesh

2 Department of Economics, Institute of Business Administration, Karachi, Pakistan

3 Department of Economics, Goa University, Taleigao Plateau, Goa, India

4 South Asian Network for Development and Environmental Economics (SANDEE), International Center for Integrated Mountain Development (ICIMOD), Kathmandu, Nepal

5 Institute Of Research And Development Pvt Ltd, Malé, Maldives

6 International Union for Conservation of Nature (IUCN), Colombo, Sri Lanka 